\title{
アンボンドブレースの動的性能 EXPERIMENTAL STUDY ON DYNAMIC に関する実験的研究 BEHAVIOR OF UNBONDED-BRACES
}

\author{
長谷川久巳 -*1 \\ 岩田 衛—*2 \\ 竹内 徹 $-* 1$ \\ 秋山 宏 - $* 4$ \\ キーワード \\ 鋼構造, 履歴ダンパー, 動的性能, 振動実験, 塑性疲労 \\ Keywords : \\ Steel structure, Hysteretic damper, Dynamic behavior
}

$\begin{array}{ll}\text { Hisami HASEGAWA }-* 1 & \text { Toru TAKEUCHI }-* 1 \\ \text { Mamoru IWATA }-* 2 & \text { Satoshi YAMADA }-* 3 \\ \text { Hiroshi AKIYAMA }-* 4 & \end{array}$

In applying dampers on structures for reducing response against seismic forces, confirming dynamic performances of such dampers are essential for guaranteeing safety of whole structural system. In this paper, axial-type elasto-plastic dampers (Unbonded Braces) are examined on full-scale dynamic test-system using shaking table with real-time response against recorded earthquake shake. As a result, dynamic performances of whole system of this type of dampers, including effect of restraint encasement, welding, local buckling, local bending etc., are confirmed and reported. The test covers maximum axial stress up to $7.2 \%$, and cumulative plastic-ratio up to 1,400 .

\section{1. 序}

阪神大震災における鋼構造骨組の梁端部の損傷およびこれらの 建築物の破壊形式が経済に与える損失の反省より，地震時のエネ ルギーを取り替え可能な复歴ダンパーに集中させ，建物主体構造 を支持する構造をできる限り弾性域に留める設計法が一般的に使 用されるようになってきている。この考え方は筆者らが提唱した 柔剛構造1)や損傷制御構造 2 の一応用例之考える事ができる。

上記設計においては，履歴ダンパーはレベル１以下の小地震か ら塑性化させ履歴減衰を発揮させることにより, 主構造をレベル 2 近くまで弾性域にとどめることが可能となる。このことにより 主構造の梁端部の歪は従来構造に比べ大幅に低減され，梁端部の 損傷を回避するのに効果的となる。その一方で履歴ダンパーの塑 性率・累積塑性率はレベル 2 入力に対しそれぞ㧈 10〜20,40〜80 に達し, 平均歪速度も通常構造部の $2 \sim 3$ 倍に達するなど, 従来構 造材に比較しかなり過酷な入力を受けることになる。このような 構造の要となるダンパーについては, その静的性能の検証”や繰り 返し疲労性能の確認 ') 等は行われてきたが, 構造物の安全性の確保 のためにはその動的塑性変形能力の検証が必須である。特に履歷 ダンパーに局部座屈等による応力集中や溶接部の脆性破壞の可能 性が予想される場合には，素材試験だけでなくダンバ一全体の動 的試験を行わなければ総合的な検証を行ったことにならない。

本論では筆者らが提案した動的実験法》により，軸降伏型履歴ダ ンパーであるアンボンドブレース（鋼管コンクリートによる座屈拘 束筋違）の動的大変形実験を行い，記録地震波応答入力に対する 同履歴ダンパーの動的加力下における最大変形能力および累積変 形能力の検証を行い報告する。

\section{2. 実医概要}

\section{1 到硢体形状}

試験体はブレースとして使われる原寸サイズとした。試験体に 用いたアンボンドブレースは，芯となるプレートを鋼管とコンク リートによって拘束することにより座屈させないようにしたブ レースで, その形状を図 1 , 写真 1 に示す。試験体は同一形状の 2 体で, No. 1 およびNo. 2 試験体とする。部材中央部の芯材断面は板 厚 $22 \mathrm{~mm}$, 幅 $130 \mathrm{~mm}$, 材質は一般構造用圧延鋼材 SS 400 で, 降伏点 は $274 \mathrm{~N} / \mathrm{mm}^{2}$, 引張り強さは $439 \mathrm{~N} / \mathrm{mm}^{2}$ である。また, 試験体長さ(芯 材長さ), 座屈拘束部(鋼管コンクリート) 長さおよび塑性化部長さ は，それぞれ $2351 \mathrm{~mm}, 1591 \mathrm{~mm}, 1291 \mathrm{~mm}$ である。

\section{2 . 2 実駼装目}

本実験で用いた赛験装置は文献 5) で提案した大型振動台上に設 置された慣性加力装置である。実験装置の略図を図 2 , 加力ジグを 図 3 , 全景を写真 2 に示す。この装置は積層ゴムとその上に設置し た合計重量 $220 \mathrm{t} 0 \mathrm{n}$ の重鍾および加振フレームに接続した試験体に よって構成され，装置の固有周期は 2.0 秒, 試験体を組み込んだ時 の弾性固有周期は 0.2 秒となっている。この実験装置の重量は, そのほとんどが重錘および加振フレームの重量であり，積層ゴム と試験体を並列ばねとした「1質点系」と見なすことができる。

\section{3 計测装是}

実験装置には変位計·加速度計をはじめとする各種センサーを設 置し, 試験体の変形状態や実験装置の各部分の挙動を計測する。主 要計測項目はピン支持された柱の頂部に作用する水平荷重, 同加 力点の水平変位㧍よびブレ一スの軸変形で, そ扎ぞれ加力梁に添 付された歪みゲージ, ストロークの大きなワイヤー変位計, 差動卜

\footnotetext{
*1 新日本製鐵(俳) マネジャー・工修

(宁100-8071 千代田区大手町2-6-3)

*2 神奈川大学 教授・工博 (当時新日本製鐵侏) 部長)

*3 東京工業大学 助教授 $\cdot$ 工博 (当時東京大学 助手)

*4 日本大学 教授・工博 (当時東京大学 教授)
}

${ }^{* 1}$ Senior Manager, Nippon Steel Corp., M. Eng.

*2 Prof., Kanagawa Univ., Dr. Eng. (Formerly, General Manager, Nippon Steel Corp.)

*3 Assoc. Prof., Tokyo Institute of Technology, Dr. Eng. (Formerly, Research Assoc., Tokyo Univ.)

*4 Prof., Nihon Univ., Dr. Eng. (Formerly, Prof., Tokyo Univ.) 
ランス変位計によって計測する。これらのデータを1/1000 秒刻み で計測した後, 高周波ノイズを落とすために 5 ステップ毎の平均 值を取って $1 / 200$ 秒刻みのデータとして収録した。

\section{4 加振手順}

実験においては，まず予備加振として小振幅のパルス波を入力 したパルス加振を行い，試験体を含む実験装置全体を自由振動さ せて固有周期と減衰を計測した。次いで本加振では記録地震波に 加速度倍率を乗ずることによって入カレベルを調整し，以下の順 序で加振を行った。

(1)弾性加振 : 試験体が塑性化しない程度の入力を行い, 弾性範 用での挙動を調べる。

(2)弾塑性加振：試験体が塑性化するレベルの入力を行う。

(3)終局加振 ：試験体の終局状態を実現するために十分な強さの 波を入力する。

入力波としては, N 0.1 試験体には兵庫県南部地震神户海洋気象 台記録波（NS 成分）を,No.2 試験体にはEL CENTRO(1940.5.18) 波 （NS 成分）を用いた。

加振の入力レベルを決定する際には, 試験体を含む加振装置を 1 質点系にモデル化した応答解析を行い, 試験体が目標とする状 態になるように加速度倍率を設定した。また，最終破壊がN 0.1 試 験体では圧縮側で, No. 2 試験体では引張り側で生じるように入力 波の位相を調整した。各試験体の加振順序を以下に示す。

No. 1 試験体 (神戸海洋気象台波 is 成分)：(1)最大速度 $10 \mathrm{~cm} / \mathrm{sec}$ (引張) $\rightarrow$ (2)最大速度 $40 \mathrm{~cm} / \mathrm{sec}$ (引張) $\rightarrow$ (3) 最大速度 $40 \mathrm{~cm} / \mathrm{sec}$ (圧縮)

$\rightarrow$ (4)最大速度 $70 \mathrm{~cm} / \mathrm{scc}$ (圧縮)

No. 2 試験体 (EL CENTR0 波 is 成分)：(1)最大速度 $5 \mathrm{~cm} / \mathrm{sec}$ (引張)

$\rightarrow$ (2)最大速度 $30 \mathrm{~cm} / \mathrm{scc}$ (引張) $\rightarrow$ (3)最大速度 $50 \mathrm{~cm} / \mathrm{sec}$ (压縮)

$\rightarrow$ (4) 最大速度 $70 \mathrm{~cm} / \mathrm{sec}($ 引張 $) \rightarrow$ (5)最大速度 $90 \mathrm{~cm} / \mathrm{scc}$ (引張)

\section{3．実跧䊅果}

\section{1 荷重一変形閣係と実検経過}

入力レベルと最大応答值の一覧を表 1 に示す。また, 弾性加振, 弾塑性加振, 終局加振の各加振ステップでのブレースの荷重 - 変形 関係について, 横軸に歪み, 縦軸に応力で表し, 図4 おうよび図 5 に 示す。ブレースの軸変形は, 入力が $40 \mathrm{~cm} / \mathrm{sec}$ までの変形時には差 動卜ランス変位計による測定值を, $70 \mathrm{~cm} / \mathrm{sec}$ 以上の変形時にはり イヤ一変位計による計測值を軸変形に換算して用いている。

\section{1）Ｎ０．１試垟体（神戸海洋気象台波ＮS 成分）}

No. 1 試験体は, ステップ(2)(3)の 2 回の $40 \mathrm{~cm} / \mathrm{sec}$ 入力に対し安 定した履歴ループを示し, 引張り側で最大 $2.6 \%$, 圧縮側で $2.9 \%$ の 最大歪が確認された。こ扎らは層間変形角でそれぞれ 1/57,1/52 であった。

ステップ(4)の $70 \mathrm{~cm} / \mathrm{sec}$ 応答に関しては, 本試験体の設計上の軸 縮み限界值 $60 \mathrm{~mm}$ (端部に㧍计る補強りブと充填モルタルとのクリ アランス, 軸歪 $4.6 \%$ に相当）以上の軸縮みに拀いてリブがモル夕 ルに衝突し耐力上昇を生じさせたが，その後も履歴ループを保持 し, 最大 $7.6 \%$ の最大压縮歪（層間変形角で $1 / 20$ ）が確認さ机た。 この時点でも芯材の破断や座屈拘束鋼管の局部座屈等の現象は確 認されなかった。

\section{2) NO. 2 試験体（EL CENTRO 波 NS 成分）}

No. 2 試験体は, (2) $30 \mathrm{~cm} / \mathrm{sec}$, (3) $50 \mathrm{~cm} / \mathrm{sec}$, (4) $70 \mathrm{~cm} / \mathrm{sec}$ の応答

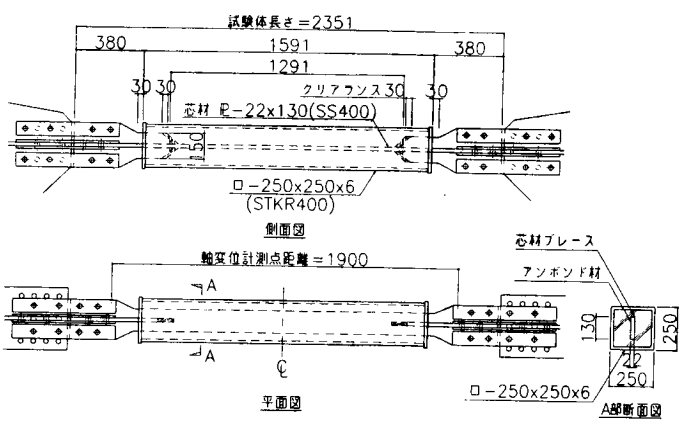

図 1，試験体形状（単位：mm）

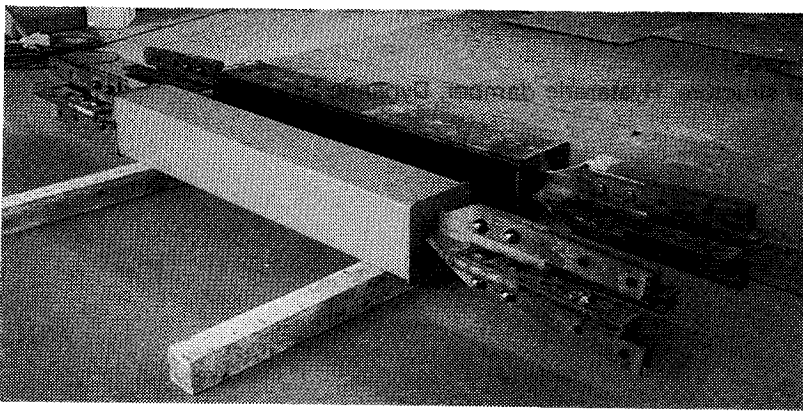

写真 1 試験体外観

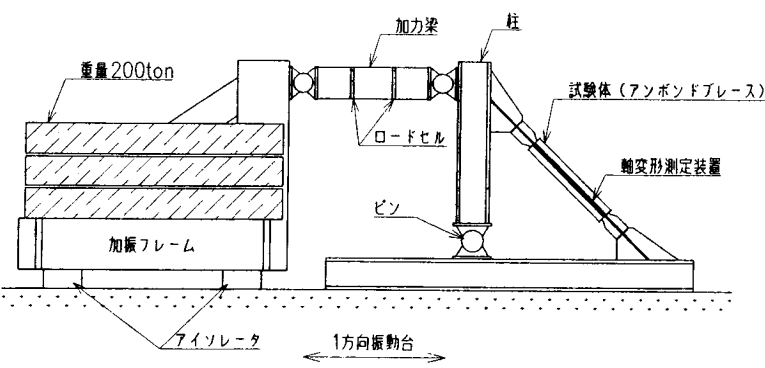

図 2 実験装置の略図

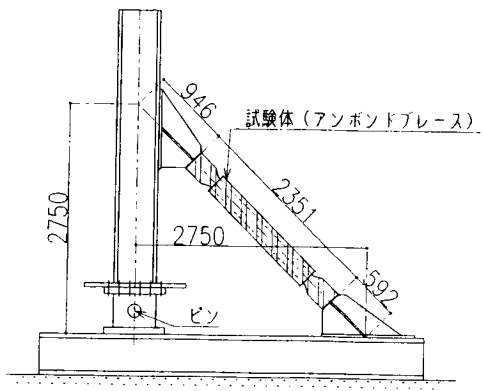

図 3 加カジグ全体図（単位：mm）

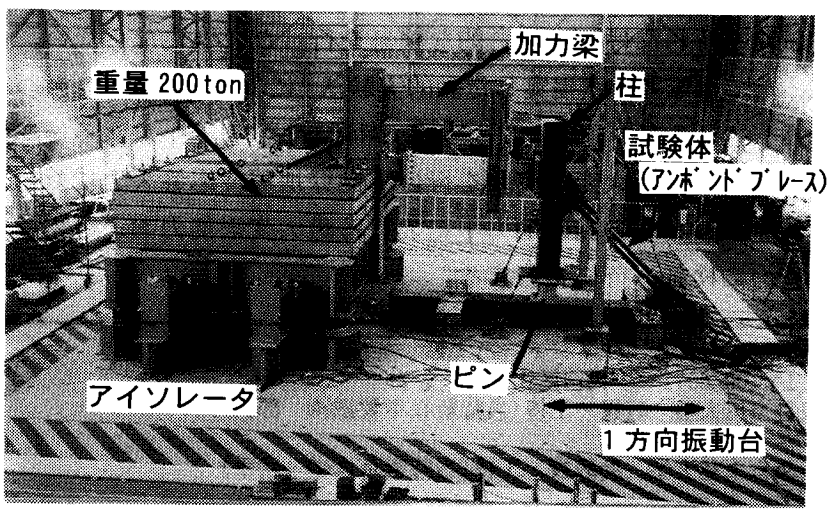

写真 2 実験装置全景 
において安定した履歴ループを示した。

ステップ(4)の $70 \mathrm{~cm} / \mathrm{sec}$ 応答時の最大歪は引張り側で $4.4 \%$, 圧 縮側で $3.1 \%$ を示した。層間変形角でそれぞれ $1 / 34,1 / 49$ であっ た。続く(5) $90 \mathrm{~cm} / \mathrm{sec}$ の入力に対し，7.2\%（層間変形角で $1 / 20$ ) の履歴ループを経た後に芯材が破断した。破断位置は試験体長さ に対し柱側からほぼ1/4の部分であった。芯材破断後は，柱側芯 材が梁側に残った鋼管コンクリートの鞘の中を移動し，压縮変形 時に破断面どうしが接触する状態が加振終了まで続いた。

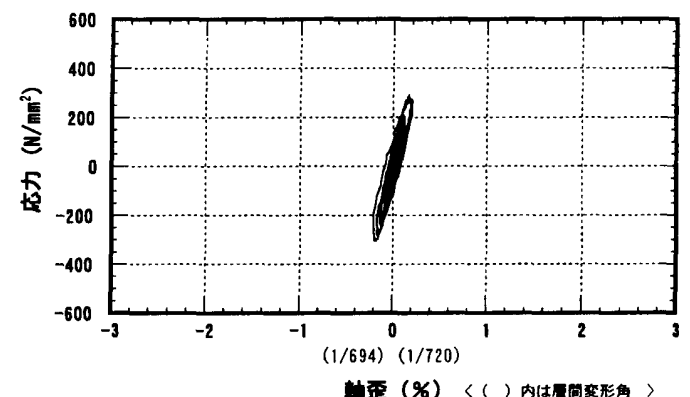

ステップ(1)：1回目加振（弾性加振 $10 \mathrm{~cm} / \mathrm{sec}$ )

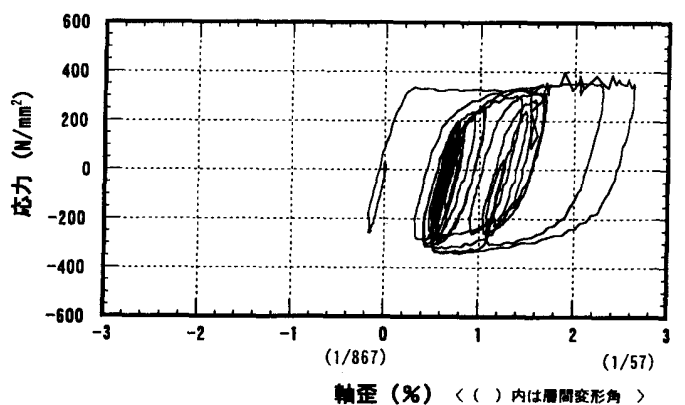

ステップ(2) : 2 回目加振（弾塑性加振 $40 \mathrm{~cm} / \mathrm{sec）}$

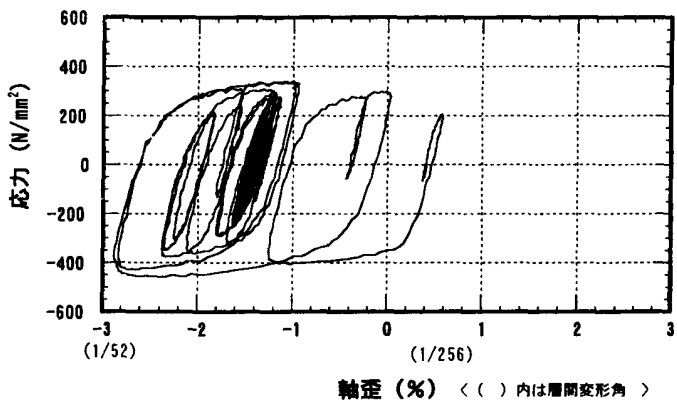

ステップ(3)：3 回目加振（弾塑性加振 $40 \mathrm{~cm} / \mathrm{sec}$ (逆位相))

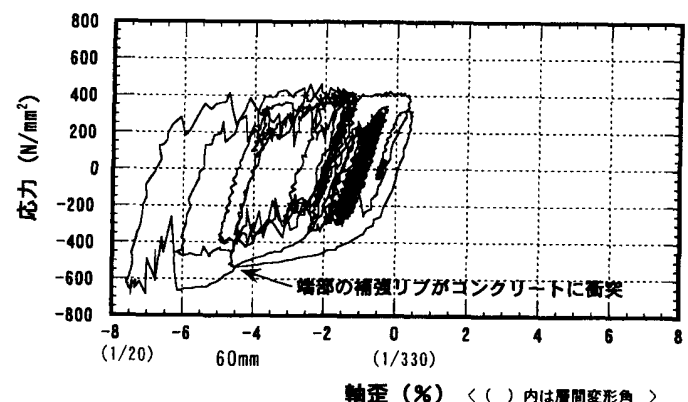

ステップ(4)：4回目加振（終局加振 $70 \mathrm{~cm} / \mathrm{sec}$ (逆位相))

図 4 各加振レベルで得られた荷重 - 変形関係 （No.1 試験体：神戸海洋気象台波 NS 成分）

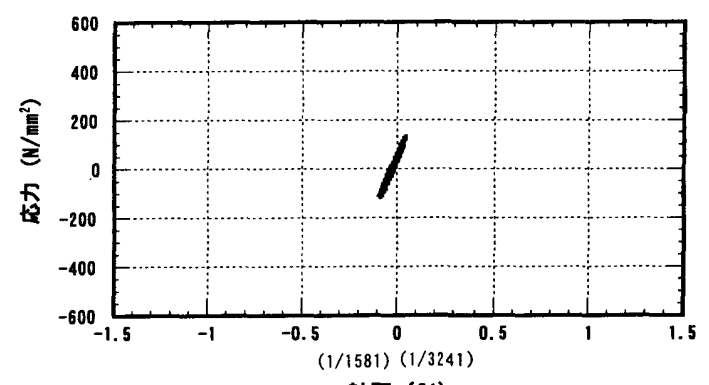

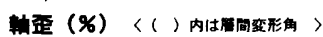

ステップ(1)：1 回目加振（弾性加振 $5 \mathrm{~cm} / \mathrm{sec}$ )

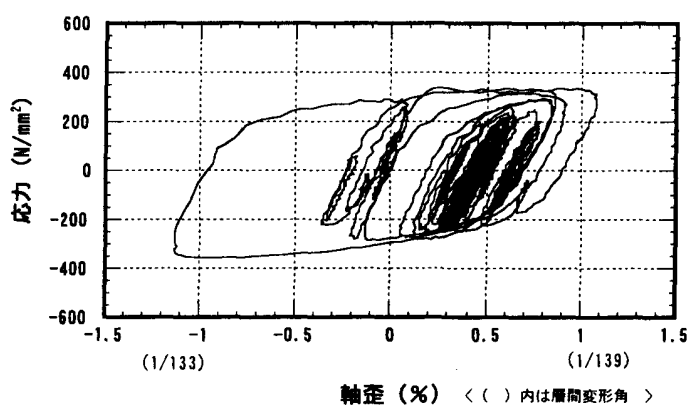

ステップ(2)：2 回目加振（弾塑性加振 $30 \mathrm{~cm} / \mathrm{sec}$ )

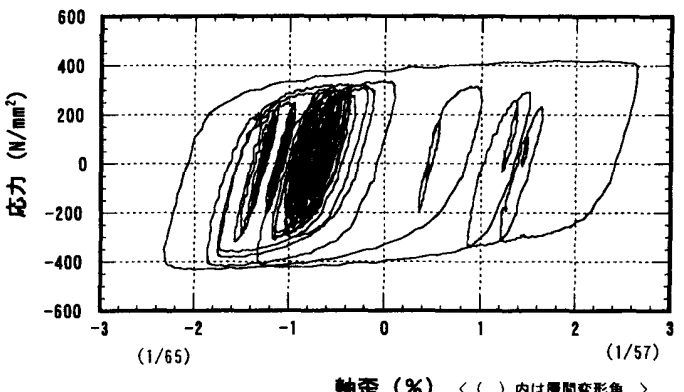

ステップ(3)：3 回目加振（弾塑性加振 $50 \mathrm{~cm} / \mathrm{sec}$ (逆位相))

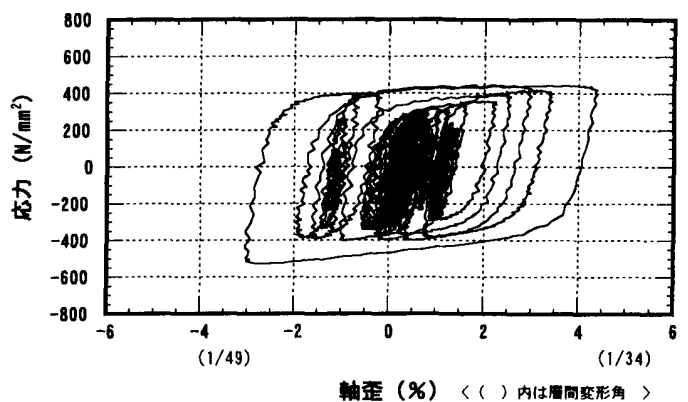

ステップ(4): 4 回目加振（弾塑性加振 $70 \mathrm{~cm} / \mathrm{sec）}$

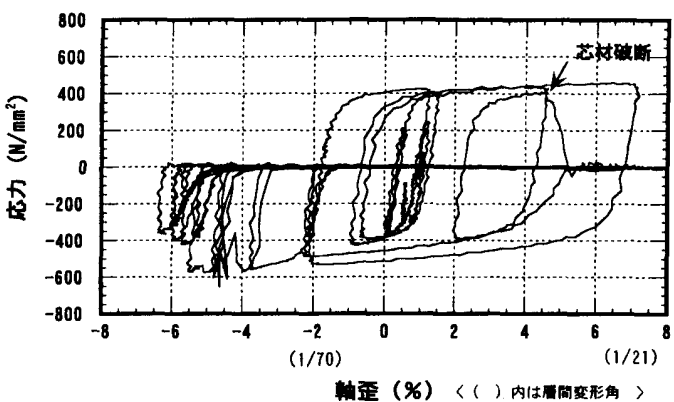

ステップ(5)：5回目加振（終局加振 $90 \mathrm{~cm} / \mathrm{sec}$ ）

図 5 各加振レベルで得られた荷重 - 変形関係 (No. 2 試験体：EL CENTRO 波 NS 成分) 


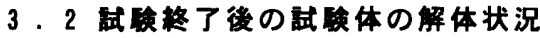

試験後, No. 1, N0. 2 両試験体を解体し，座屈拘束鋼管内の芯材の 状況を確認した。解体後の芯材の写真を写真 3 に示す。

圧縮で破壊させた No. 1 試験体は, $70 \mathrm{~cm} / \mathrm{sec}$ 入力時に生じた端部 補強リブとモルタルの接触により, リブとの接触部分のモルタル が圧壊していた。その他の部分においては，モルタル，鋼管ともに 変形等は認められなかった。

引張り側で破壊させた No. 2 試験体は，端部の補強リブ先端から $5 \mathrm{~cm}$ 程度部材中央寄り（芯材長さの $1 / 4$ 近傍）の芯材部が破断し ていた。これはリブ先端における応力集中とともにフレームから の曲げが影響したものと考えられる。

両試験体とも芯材に局部座屈は認められず，目視で確認できる 波打ち変形も見られなかった。

\section{3 エネルギー吸収能力と㘹性变形能力}

それぞれの試験体の吸収した総歪エネルギ一量 (Wp $)$ および等価 累積塑性変形倍率 $\left(_{\mathrm{E}} \eta\right)$ を表 2 に示す。最終的に破断に至った No. 2 試験体における等価累積塑性変形倍率は1420であった。

No. 2 試験体の実験結果を別途行った実大アンボンドブレースの 疲労実験結果 ${ }^{6) 7)}$ 上に評価したものを図 6 に示す。同図は横軸に塑 性部最大軸歪 $(\%)$, 縦軸に累積塑性軸歪量 $(\%)$ をとり，さまざまな 鋼種のアンボンドブレースにおける芯材破断に至るまでの累積変 形能力を示す。定常振幅の疲労試験に対し, 本実験結果はランダ 厶応答中の最大值を横軸に評価したものであるが, 同結果は疲労 実験から得られた疲労曲線と良い对応を示しており，本形式のア ンボンドブレースにおいては, 動的荷重による著しい累積変形能 カの低下はみられなかった。

\section{4. 結到}

軸降伏型履歷ダンパーであるアンボンドブレース（鋼管コンク リートによる座屈拘束筋違）について実大振動台実験を行った。実 験結果から以下の結論を得た。

1) 動的な加力に対しても, 引張り・圧縮ともに塑性化部におけ

る軸歪 $7 \%$ 以上の安定した履歴性能が確認さ扎た。

2 ）実地震応答速度加振に対しても, 累積塑性率 1400 以上とダン パーとして十分な累積変形能力を有することが確認され，別途 実施した疲労実験結果と良い対応を示した。

\section{政}

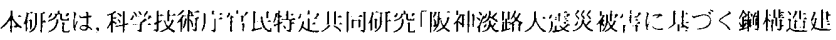

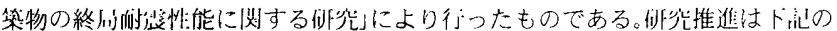
委り会糺織により行った。

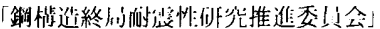

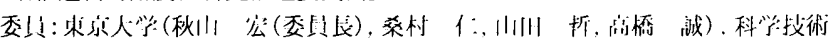

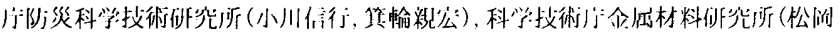

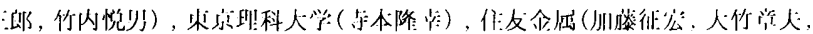

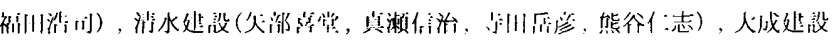

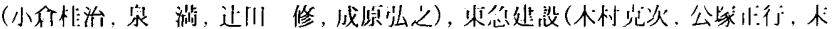

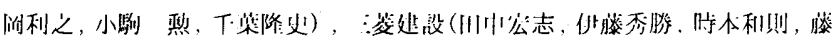

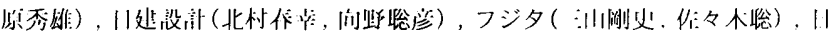

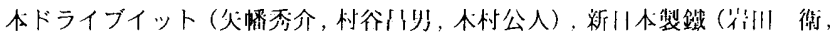

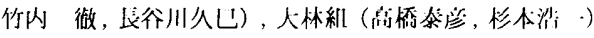

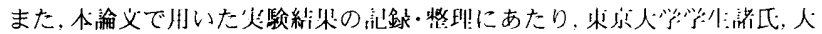

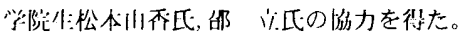

\section{考文献}

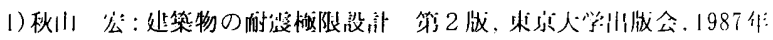

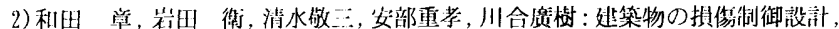
丸善, 1998 作

3)侮伯英一郎，前田泰戈，中村秀间，緑川光证，和田 裳：尖大アンボンドブ

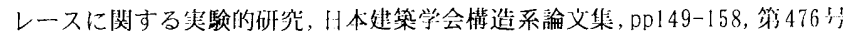

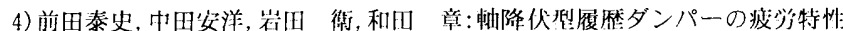

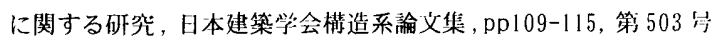

5)秋山 宏, 山田 哲, 筫輸視宏, 寺本隆幸, 大竹章夫, 矢部善堂: 惯性扣力装

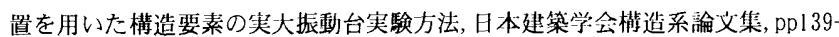
146 , 第 505 号

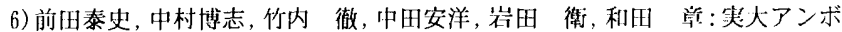
ンドブレースの疲労性能(その 1 : 実験計画と結果概要), 1999年曰日本建築学会大 会 (中国) 学術講演梗概集 C-1, pp. 813-814，1999 年 9 月

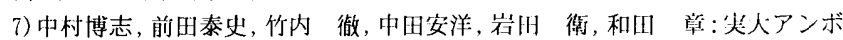
ンドブレースの疲学性能(その 2 :実験絬果)，1999年日本建築学会大会(中心) 学術講演梗概集C-1，pp. 815-816，1999 年 9 月

表 1 入カレベルと最大応答值一覧

\begin{tabular}{|c|c|c|c|}
\hline & & $\begin{array}{c}\begin{array}{c}\text { 神市海洋気象台波 } \\
\text { (NSS成分) }\end{array} \\
\end{array}$ & $\begin{array}{l}\text { EL CENTRO波 } \\
\text { ( NS成分) } \\
\end{array}$ \\
\hline $\begin{array}{l}\text { (1)彈性加振 } \\
\text { (レベル1) }\end{array}$ & $\begin{array}{l}\text { スカレベル } \\
\text { 軸变形 (歪) } \\
\text { 層間変形角 }\end{array}$ & $\begin{array}{c}V_{\max }=10 \mathrm{~cm} / \mathrm{sec} \\
\left(\mathrm{Amax}=91 \mathrm{~cm} / \mathrm{sec}^{2}\right) \\
28 \mathrm{~mm}(-0.2 \%) \\
1 / 694\end{array}$ & $\begin{array}{c}V \max =5 \mathrm{~cm} / \mathrm{sec} \\
\left(A \max =52 \mathrm{~cm} / \mathrm{sec}^{2}\right) \\
-1 \mathrm{~mm}(-0.1 \%) \\
1 / 1620\end{array}$ \\
\hline \multirow[t]{2}{*}{$\begin{array}{l}\text { (2)弾塑性加振 } \\
\text { (レベル2 })\end{array}$} & $\begin{array}{l}\text { 入カレベル } \\
\text { 軸变形 (歪) } \\
\text { 層間変形角 }\end{array}$ & $\begin{array}{c}V \max =40 \mathrm{~cm} / \mathrm{sec} \\
\left(A \max =363 \mathrm{~cm} / \mathrm{sec}^{2}\right) \\
34 \mathrm{~mm}(2.6 \%) \\
1 / 57\end{array}$ & $\begin{array}{c}V \max =30 \mathrm{~cm} / \mathrm{sec} \\
\left(A \max =311 \mathrm{~cm} / \mathrm{sec}^{2}\right) \\
-15 \mathrm{~mm}(-1.1 \%) \\
1 / 133\end{array}$ \\
\hline & $\begin{array}{l}\text { 入カレベル } \\
\text { 軸变形 (歪) } \\
\text { 層間変形角 }\end{array}$ & $\begin{array}{c}V_{\max }=-40 \mathrm{~cm} / \mathrm{sec} \\
\left(A \max =-363 \mathrm{~cm} / \mathrm{sec}^{2}\right) \\
-37 \mathrm{~mm}(-2.9 \%) \\
1 / 52\end{array}$ & $\begin{array}{c}V_{\max }=-50 \mathrm{~cm} / \mathrm{sec} \\
\left(A \max =518 \mathrm{~cm} / \mathrm{sec}^{2}\right) \\
34 \mathrm{~mm}(2.7 \%) \\
1 / 57\end{array}$ \\
\hline \multirow[t]{2}{*}{$\begin{array}{l}\text { (3)終局加振 } \\
\text { (レベル 3) }\end{array}$} & $\begin{array}{l}\text { 入カレベル } \\
\text { 軸变形 (歪) } \\
\text { 層間变形角 }\end{array}$ & $\begin{array}{c}V \max =-70 \mathrm{~cm} / \mathrm{sec} \\
\left(A \max =-636 \mathrm{~cm} / \mathrm{sec}^{2}\right) \\
-98 \mathrm{~mm}(-7.6 \%) \\
1 / 20 \\
(\text { コンクリート压壊) }\end{array}$ & $\begin{array}{c}V \max =70 \mathrm{~cm} / \mathrm{sec} \\
\left(A \max =724 \mathrm{~cm} / \mathrm{sec}^{2}\right) \\
57 \mathrm{~mm}(4.4 \%) \\
1 / 34\end{array}$ \\
\hline & $\begin{array}{l}\text { 入カレベル } \\
\text { 軸変形 (歪) } \\
\text { 層間変形角 }\end{array}$ & & $\begin{array}{c}V_{\max }=90 \mathrm{~cm} / \mathrm{sec} \\
\left(A \max =932 \mathrm{~cm} / \mathrm{sec}^{2}\right) \\
93 \operatorname{mm}(7.22 \%) \\
1 / 21(\text { 芯材破断) }\end{array}$ \\
\hline
\end{tabular}

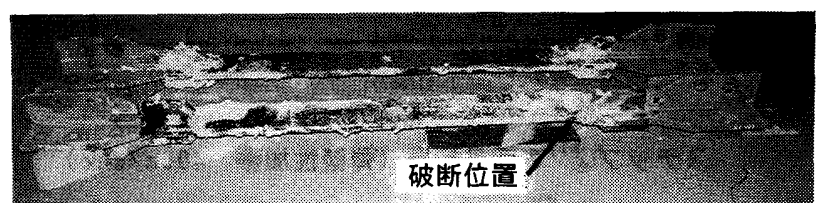

写真 3 試験後の解体状況 (奥: No.1 試験体, 手前: No.2 試験体)

表 2 吸収歪エネルギー $(W p)$ と等価累積塑性変形倍率 $(\varepsilon n)$

No.1 試験体：神戸海洋笑象台 NS 成分

\begin{tabular}{|c|c|c|c|c|c|}
\hline 加振レベル & (1) $10 \mathrm{~cm} / \mathrm{sec}$ & (2) $40 \mathrm{~cm} / \mathrm{sec}$ & $\begin{array}{l}\text { (3) } 40 \mathrm{~cm} / \mathrm{sec} \\
\text { (逆位相) }\end{array}$ & $\begin{array}{l}\text { (4) } 70 \mathrm{~cm} / \mathrm{sec} \\
\text { (逆位相) }\end{array}$ & 合計 \\
\hline$\overline{W p}(\mathrm{KN}-\mathrm{cm})$ & 1426 & 19459 & 19477 & 58740 & $\overline{99102}$ \\
\hline$\xi \eta$ & 9 & 124 & 124 & 374 & 631 \\
\hline
\end{tabular}

No. 2 試験体：EL CENTRO NS 成分

\begin{tabular}{|c|c|c|c|c|c|}
\hline 加振レベル & (2) $30 \mathrm{~cm} / \mathrm{sec}$ & $\begin{array}{c}\text { (3) } 50 \mathrm{~cm} / \mathrm{sec} \\
\text { (逆位相) }\end{array}$ & (4) $70 \mathrm{~cm} / \mathrm{sec}$ & (5) $90 \mathrm{~cm} / \mathrm{sec}$ & 合阡 \\
\hline Wp $(\mathrm{KN} \cdot \mathrm{cm})$ & 19179 & 37257 & 80444 & 86069 & 222949 \\
\hline & 122 & 237 & 513 & 548 & 1421 \\
\hline
\end{tabular}

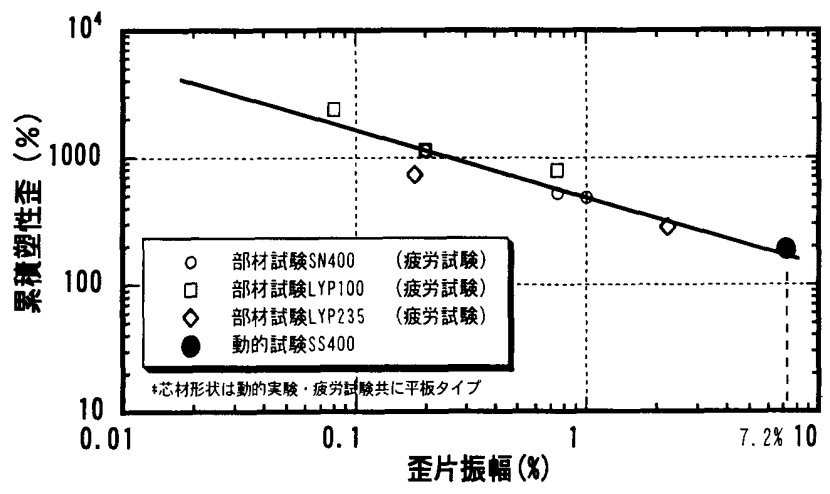

図 6 歪振幅と疲労累積歪との関係

[1999年 4 月20日原稿受理１999年 7 月27日採用決定］ 